Volume 6 Issue 4, December 2019

Nationally Accredited Journal,

Decree No. B/4130/E5/E5.2.1/2019

\title{
Juridical Analysis of the Implementation on Project of National Agrarian Operations (PRONA) In the Regency of Blora
}

\begin{abstract}
Wahyu Arga Kurniawan ${ }^{1}$ and Akhmad Khisni ${ }^{2}$
Abstract. Blora Regency is one of regencies in east end of Central Java province of the run National Agricultural Operations Program or commonly referred to PRONA. In fiscal year 2017 this amount PRONA in Blora Regency is one of the largest in Central Java province that is the number 25000 certification of land. Implementation of the National Agricultural Operations Program also involves various parties including the Government of Blora, Blora Regency Land Office and Regency Head / Head of Village related to the implementation of the National Agricultural Program's operation. Research methods which I use in this research is empirical juridical. Moreover, I also use this type of field research where the author falls directly to secure the data is valid in the field. From the results of this study concluded that the juridical implementation of the National Agricultural Program Operation in Blora with fiscal year 2017 is superbly accomplished in accordance with applicable regulations is Government Regulation No. 24 of 1997 on Land Registration and Technical Guidelines Prona. Keywords: National Operations Program; Registration of Land Mass.
\end{abstract}

\section{Introduction}

In essence, humans have primary needs that consists of clothing, food, and shelter. Land is one of the primary needs of man coming on board or group of human habitation. Land as a gift of God Almighty the natural resources indispensable to meet the needs of human beings. Besides land was also a major contributing factor in life and welfare of the people in any other country not Indonesia. ${ }^{3}$

Given the importance of soil for human life, then the land can be used as a means for the welfare of the Indonesian people, so it needs the intervention of the state to regulate it in accordance with the mandate of Article 33 paragraph (3) of the Constitution of the Republic of Indonesia of 1945, which stated that "Earth and Water and natural riches contained therein controlled by the state and used for the prosperity of the people. "

Not only that, the government also gave legal protection of the land contained in the Act No. 5 of 1960 on Basic Regulation of Agrarian often known by BAL.

In addition to the Law No. 5 of 1960, the government also made the Government Regulation No. 10 of 1961 on Land Registration. Along with the development of the times the Government Regulation No. 10 of 1961 was not in accordance with the legal requirements that exist in society then stated Government Regulation No. 24 of 1997 on Land Registration and also claimed the Government Regulation No. 10 of 1961 does not apply anymore. Definition of land registration in Regulation government No. 24 of 1997 contained in article 1 point 1.

\footnotetext{
${ }^{1}$ Students of the Faculty of Law Master of Notary Program UNISSULA email warga067@gmail.com

${ }^{2}$ Lecturer, Faculty of Law, Sultan Agung Islamic University, Semarang, email khisni@unissula.ac.id

${ }^{3}$ Soejono and Abdurrahman, 1998, Prosedur Pendaftaran Tanah Tentang Hak Milik Sewa Guna dan Hak Guna Bangunan, Jakarta: Rineka Copyright, p.1
} 
Registration of land for the first time systematically implemented through registration and sporadic land registration. Land registration systematically implemented over the idea of the National Land Agency of the Republic of Indonesia which is based on a long-term work plan and annual plans are sustainable. While sporadic land registration carried out at the request of interested parties, namely the party entitled to object registration of the land in question. ${ }^{4}$

Definition of land registration in the Government Regulation No. 24 of 1997 is a refinement of the scope of activities of land registration pursuant to Article 19 paragraph (2) PP No.10 of 1961 only include: measurement, mapping, and soil bookkeeping, registration and transfer of land rights and provision of evidentiary proof of rights as a powerful tool. ${ }^{5}$

In Indonesia, the land is often the object of dispute and disagreement public. One example of community activities that can lead to conflicts over land, namely, buying and selling land and soil were used as collateral in financial institutions such as banks. Basically the thing that triggered the conflict for land sales in the absence of a clear certificate or even without a certificate. In the region of the Indonesian state owned most of the land that the community has not been certified and is generally found in villages where people are not familiar with the law of the land. In general, the soils there are still a pethuk course.

Legal guarantee to be realized in this land registration, including the certainty of status rights in the list, the certainty of the subject of rights, and the rule of the right object. In order to realize the legal guarantee of the right to land, the government issued Decree No. 189 of the Minister of Internal Affairs in 1981 on the National Agrarian Operations Project. Implementation of the National Operations Project or commonly referred to in the form sertification of PRONA land mass and settlement of land disputes that are strategic. PRONA program is addressed to people with weak economic groups. Implementation PRONA carried throughout the Regency and Municipalities throughout Indonesia and specified in groups. Responsibility PRONA submitted by each of the Regional Executive and will be accountable to the Director General of Agricultural. Prona the activities funded by the government through the state budget in order to give certainty to the community land rights with the certification of the mass of land areas that have been held or have been held by the economically disadvantaged.

Blora Regency is a regency in Central Java PRONA conducting the responsibilities delegated by the National Land Agency Blora. In 2017, there were 29 villages in the regency of Blora who follow this program with the target certificate PRONA about $15,000 .{ }^{6}$ But many constraints experienced by the National Land Agency is to implement the Project for National Operations Agrarian, one that is less public about PRONA this, many people who think this program shall be entirely borne by the government, but in reality the government costs in the form of counseling, measurement, inspection , SK publishing rights, issuance of certificates, supervision, and reporting. While costs in participants Prona form, right / evidence acquisition, boundary markers, stamp duty, and PPH and less cost in participants spend around Rp. $250,000.00$ and pay in the local regency.

\footnotetext{
${ }^{4}$ Boedhi Harsono, op.cit., p. 487

${ }^{5}$ Mhd. Yamin Lubis and Abd. Rahim Lubis, 2008. Hukum Pendaftaran Tanah, Bandung: Mandar Maju, p. 38

${ }^{6}$ http://suarabanyuurip.com/mobile/baca/di-blora-sertifikat-prona-tak-gratis The accessed date October 18,2017 at 15:25
} 
Volume 6 Issue 4, December 2019

Nationally Accredited Journal,

Decree No. B/4130/E5/E5.2.1/2019

With the project's PRONA in Blora regency which has the objective to provide legal certainty to land and resolve land disputes that are strategic to the people of Blora, especially for people who get in on the weak. Therefore the authors are interested to learn and explore more about the National Agricultural Operations Project (PRONA) in Blora this.

Based on the above background, this study aims to determine the juridical implementation of the National Agricultural Operations Project (PRONA) in Blora and to identify the constraints faced by the Government of Blora who bestowed upon the National Land Agency Blora.

\section{Research methods}

The method which I use is empirical juridical approach. ${ }^{7}$ In this study, the authors will collect, identify objectively in order to give a real picture of the Project implementation of the National Agricultural Operations (PRONA) in Blora .Type of study in this study are more descriptive because this study aims to provide an overview of the state of the subject or object of research as it is. ${ }^{8}$ The data source consists of primary data that some of the information or facts, as well as interviews and secondary data in the form of books about indigenous customary law and inheritance cases in Indonesia, as well as literature relating to the cases. Data collection techniques with interviews and observations, as well as the study of literature. Data analysis technique is descriptive qualitative research.

\section{Results And Discussion}

\subsection{Agrarian National Operations Project Implementation (PRONA) in Blora}

Implementation of the National Agricultural Operations Program or commonly referred to PRONA has been regulated in regulations of the Minister of Agrarian and Spatial Planning / Head of National Land Agency of the Republic of Indonesia Number 5 of 2015 concerning the National Agricultural Program.

In the mentioned regulatory directives PRONA implementation of PRONA object to reporting PRONA implementation. As mentioned in the regulation which is the object PRONA soil, soil that can become the object of PRONA has several criteria: (1) land used to belong to indigenous; (2) Soil directly controlled by the state; (3) The land is located in the village overlay; (4) agricultural land; (5) Land owned by a legal entity / social and religious institutions.

PRONA activities carried out in the area of the Village / Village systematically and implemented gradually. Head of the regency Land Office was in charge of the implementation of the National Agricultural Operations Program. Head of the Land Office is obliged to form committees in every stage to run PRONA activities, the organizers implementation of activities of the National Agricultural Operations can both be taken from within the Ministry of Agricultural and Spatial Planning / National Land Agency or by the village which is the object of the National Agricultural Program

\footnotetext{
7Juridical empirical approach is a study that seeks to identify the law contained in the community with a view to knowing other symptoms, See Amiruddin \& Zainal Asikin, Pengantar Metode Penelitian Hukum, Mataram: Book College Division PT. King Grafindo, 2003, p. 19. ${ }^{8}$ Soerjono Soekanto, Pengantar Penelitian Hukum, Jakarta: Sinar Grafika, 1988, p. 12.
} 
Operation. Sources of financing for the National Agricultural Operations Program comes from the State Budget (APBN) and Regional Budget (APBD).

The delivery of PRONA activities can be carried out in stages in accordance with the results already achieved. The delivery of PRONA activities shall be submitted to the landlord no later than the fourth week of December of the current budget year. In addition, Head of the Land Office must report the results PRONA activity that has been completed in stages to the Minister of Agrarian and Spatial Planning / Head of National Land Agency through the Head Office of the National Land Agency.

With the issuance of Decree of the Minister of Home Affairs Number. 189 of 1981 on PRONA, in principle, the National Operations Project Agricultural or PRONA which is usual emphasis on the economically disadvantaged, while for the people who actually entered in the class can not afford not charged a fee. ${ }^{9}$

Working range of Agrarian National Operations Project (PRONA) include: (1) the certification of the land mass; (2) Extension agrarian laws; and (3) Inventory of land disputes. ${ }^{10}$

National Operations Project (PRONA) has two related institutions which include: (a) At the level of Village and (b) At the level of the Land Office. Projects in National Operations Agrarian (PRONA) Land Office Blora regency is divided into several stages, namely: (1) Preparation, (2) Activity Coordination, (3) Data collection juridical, (4) The collection of physical data, (5) Measurement , (6) Issuance of Measure, (7) Examination of the Land, (8) Announcement, (9) the Decision to Grant Rights, (10) Certification process, and (11) Delivery of Certificates.

The cost of PRONA also contained in the Decision of the State Minister of Agrarian Affairs / Head of National Land Agency Number 4 of 1995 concerning changes in the cost of charge in order to award land rights derived from the grant of rights on state land, the affirmation of customary land rights and the conversion of the former customary land rights the project which is the object of the National Agricultural Operations (PRONA).

With the publication of Agrarian Ministerial Decree No. 4 of 1995, then the landowner can take care of land documents easily, quickly, and cost and are mainly targeted to society the weak economy. In the provisions of article 2, paragraph (2) Agricultural Ministerial Decree No. 4 of 1995, the cost of granting administrative rights on state land, as well as confirmation or recognition of indigenous land rights have been specified.

Meanwhile, if there are other charges that go including the above provisions that often are associated with PRONA is can be classified as Illegal Payments (extortion) and illegal and an act prohibited (Article 8 Agricultural Ministerial Decree No. 4 of 1995). Thus government efforts in order to foster passion and raise awareness of the economically disadvantaged to administer and resolve land tenure rights for a small fee in accordance with the Decree of the Minister of Agrarian No. 4 of 1995.

\subsection{The Problems that Occur in the Implementation Program of the National Agricultural Operations}

First, Problems in the Land Office. In running Program Project National Operations Agrarian (PRONA) The Regency Land Office Blora facing various problems as follows: (a) Total quantity PRONA too much, (b) Lack of human resources Land Office, (c) Lack

\footnotetext{
${ }^{9}$ See Article 19 paragraph (4) of Law No. 5 of 1960 on Basic Regulation of Agrarian.

${ }^{10}$ Djoko Prakoso, Ari Budiman Perwanto, 1985. Mekanisme Fungsi Agraria, Jakarta: Ghalia Indonesia, p. 45
} 
Volume 6 Issue 4, December 2019

Nationally Accredited Journal,

Decree No. B/4130/E5/E5.2.1/2019

of field equipment, (d ) HR village less knowing, and (e) Administration in the village negligible / extremely alarming.

In addition to the above constraints Land Office also experience other constraints such as: (1) Physical Aspects. State area / village carry out programs PRONA very far from difficult to reach by the committee PRONA, (2) Aspect Officer. Blora regency government have constraints in terms of time to complete the revision of the concept of DSS with Blora Regency Land Office is due to the time given to correct SPK too narrow. In addition to the time of drawing SPK narrow, preparation of SPK between Blora with the Regency Land Office Blora in the framework of the implementation of the Program Project National Operations Agrarian or the call with PRONA often delayed because one of the parties in the meeting of adjustment corrections are often not in place or discussion the old against the problem.

Second, problems in society, among others: (1) Not all the people accepted the Program PRONA, since most people assume that the process to obtain a certificate is always difficult, complicated, and requires a high cost, (2) Given the difficulties of a technical nature, among others: (a) Completion of the blank is not the same as the data source, incomplete, incorrect, and some have handed a blank empty, simply signed by the applicant, (b) In a history of the land there is not sequential, not continuous, (c) in many data entry blank streaks because of errors are not corrected with a new blank wrong but simply crossed out and initialed only, (d) Object / soil is certified but enrolled again,(E) The owners of land do not want to show the data lands or not ready to place / location of the land at the time of measurement of land, (f) In the village there is the applicant's name so that the same could happen fault designation object PRONA, (g) SPPT UN attached in the file not a SPPT UN of the object that was registered, $(\mathrm{h})$ the applicant be skeptical because they feel all affairs already all to the village so as not proactive about the completeness of the file or the requirements are less, (i) Books $C$ village much has been damaged making it difficult to cross-checking data, and ( $j$ ) the existence of the village which makes $C$ the new village.(G) SPPT UN attached file is not an SPPT UN of the object that was registered, (h) the Applicant be skeptical because they feel all affairs already all to the village so as not proactive about the completeness of the file or the requirements are less, (i) Books $C$ village much has been damaged making it difficult to cross-check the data, and (j) the existence of the village which makes $C$ the new village.(G) SPPT UN attached file is not an SPPT UN of the object that was registered, (h) the Applicant be skeptical because they feel all affairs already all to the village so as not proactive about the completeness of the file or the requirements are less, (i) Books $C$ village much has been damaged making it difficult to cross-check the data, and (j) the existence of the village which makes $C$ the new village. ${ }^{11}$

\subsection{Efforts Guide for Conducting Settlement of Problems Arising from the National Agricultural Operations Program}

To overcome these problems the Land Office to cope with a variety of ways: (1) Aspect Officer, among others, (a) The establishment of a task force juridical to accompany, guide, create files that are financed by the state budget, (b) Program PRONA above named Program County Government supported by Parliament. Then

${ }^{11}$ Mujiono A.Ptnh, Head of Blora District Land Office, Wawancara Pribadi, Blora, December 18th, 2017, 11:00 AM 
poured in decision-regent and then by the regency government socialized to the subregency and village heads, (c) Conduct recruitment of contract personnel to help overcome the shortage of administrative personnel, (d) Cooperating with surveyors through the procedure of employment contract, (e) Develop implementation schedule carefully taking into account the capabilities and availability of human resources and in comparison to the volume of existing work, (f) Preparation of program implementation PRONA much earlier,

Efforts Settlement in the Community, among others: (1) At the time of extension officers fully explain the matter of a technical nature so that the problems of a technical nature can be minimized, (2) Extension intensively that the implementation Prona subsidized by the government, (3) Urge PTSL officers to help provide guidance on the requirements that are less known by the public.

\subsection{Level of Legal Awareness and Community interest in the implementation of the National Agrarian Reform Land Certification Program Through PRONA in Blora}

Legal consciousness is an abstract concept of harmony between human beings on the appropriate order and peace. In other words, to achieve a harmony between the order and harmony, there must be awareness to act in accordance with the rules and regulations that are considered correct according to the rules of the State law. It is not merely something that grows spontaneously in the heart of society. It must be acknowledged that the legislation is communicated to the public is the first step in raising awareness of the law.

There are several indicators that can be used to measure the level of public awareness in land certification through PRONA in Blora. The indicator used to measure public legal awareness among others: (1) Registration on the obligation to register the land; (2) The public perception regarding land ownership; (3) The desire of respondents to certify the land. People are realizing that the ownership certificate is important as proof of land ownership. However, the ownership of the certificate is considered necessary only when the land sold or transferred to third parties outside the family line or outside the local area.

An understanding of the importance of the certificate as valid proof and strong according to the Indonesian agrarian law in society can be said to be low Blora. They do not understand that with the certificate then the rights and duties as landowners are legally protected by the State. As proof of ownership of the land they rely on the perception of the deed of sale. They have the perception that as long as the land is physically located within their control, both lived, passed on or used by others with their knowledge, they have full rights to the land. Perception is what makes people not motivated to land sertification.

As perceived legal awareness shape people's behavior toward the rule of law, the higher the level of public awareness, the better their knowledge of the applicable law and its contents.

Constraints are no less important and related to the legal consciousness is the availability of sufficient information on the rules of land registration. The provision of land information center should be able to be an appropriate means to encourage people in the land register.

Certify the public interest in the land can be seen from the information that is found by the community. Information needed as the basis for decision-making requires a calculation regarding the action to be performed, the results achieved and the 
Volume 6 Issue 4, December 2019

Nationally Accredited Journal,

Decree No. B/4130/E5/E5.2.1/2019

possibilities that the results will be achieved happen. In addition, the decision must also be based on the establishment of a specific value to each results will be achieved.

\section{Closing}

\subsection{Conclusion}

First, implementation of the registration of land rights through the National Agricultural Program Operation in Blora has been run by 9 steps that have been defined by the Ministry of Agricultural and Spatial Planning / Head of National Land Agency of the Republic of Indonesia from the step until the issuance of the certificate. In cases charging the applicant only charged for stamp duty and purchase stakes. From year to year the number of fields is always increasing budget proves the seriousness of the government through the Land Office Blora in ensuring the protection and legal certainty of land rights owned and controlled by the community. In addition, with the implementation registration of land rights through agrarian national operational programs in Blora, means Blora Regency Land Office has been carrying out its functions as the Decree of the Minister of 189 of 1981, No. 220 of 1981 and No. 266 1982 as well as the Technical Guidelines Prona activity in 2013.

In addition, the problems experienced by Blora Regency Land Office in carrying out the National Agricultural Program Operations include: (1) lack of public awareness of population administration such as ID card, KK, and the death certificate be one cause of delays in the implementation of the National Agricultural Operations Program; (2) The geographic location far from each other so that it takes longer; (3) The vagueness mark / peg soil due to breakdown of plot heir; (4) Lack of adequate equipment in carrying out the measurement process; (5) Lack of field officers to perform the measurement.

Second, with many obstacles experienced Blora Regency Land Office is also taking various measures to facilitate and accelerate the operation of the National Agricultural Program: (1) For people who have problems with the administration of residence such as ID cards can fill the letter of ownership; (2) of the Land Office worked with the mapping / measurement to add to the clerk at the measurement with a particular contract term.

\subsection{Suggestion}

First, National Agricultural Operations Program participants must be more closely in providing the data required for the certification process through the National Agricultural Operations Program, in order to avoid delays in the issuance of the certificate.

Second, should be carried out counseling more intensive by the Office of the National Land Blora on society candidates Operations Program's National Agrarian order to reduce the difference in public perception regarding the purpose and objective of Operations Program of the National Agricultural, the benefits of ownership certificate for the public and reduce errors in technical fields Causes certificate be processed late or left of the completed certificate requirements.

Third, giving the stock of knowledge to the committee of the National Agricultural Operations Program on duty in order to understand how the land registration through the National Agricultural Operations Program. 
Fourth, coordination between rural / village targeted by the National Agricultural Operations Program is further enhanced

\section{References}

\section{Books}

[1] Harsono, Boedi. 1999 Hukum Agraria Indonesia: Sejarah Pembentukan UndangUndang Pokok Agraria, Ed.Rev., Cet. 8th, Jakarta: Djambatan.

[2] Lubis, Mhd. Yamin and Abd. Rahim Lubis, 2008. Hukum Pendaftaran Tanah, Bandung: Mandar Maju

[3] Amiruddin \& Zainal Asikin, Pengantar Metode Penelitian Hukum, Mataram: Book College Division PT. King Grafindo, 2003

[4] Prakoso, Djoko, et al. 1985. Mekanisme Fungsi Agraria, Jakarta: Ghalia Indonesia.

[5] Soehadi, R. Land Dispute Resolution 2008. Penyelesaian Sengketa Tanah Sesudah Berlakunya Undang-Undang Pokok Agraria, Surabaya: Offset Printing Business.

[6] Soejono and Abdurrahman, 1998, Prosedur Pendaftaran Tanah Tentang Hak Milik Sewa Guna dan Hak Guna Bangunan, Jakarta: Rineka Reserved.

[7] Soekanto, Soerjono.1988. Pengantar Penelitian Hukum, Jakarta: Sinar Grafika.

\section{Website / Internet}

[1] http://suarabanyuurip.com/mobile/baca/di-blora-sertifikat-prona-tak-gratis accessed date October 18, 2017 at 15:25

\section{Laws and regulations}

[1] Law No. 5 of 1960 on Basic Regulation of Agrarian.

[2] Interior Minister Decree No. 189 of 1981 on the National Agrarian Operations Project.

[3] Regulation of the Minister of Agrarian and Spatial Planning / Head of National Land Agency Number 4 Year 2015 on the National Agricultural Program (PRONA).

[4] Government Regulation No. 24 of 1997 on Land Registration.

[5] Government Regulation No. 46 Year 2002 on Tariff Applicable at the National Land Agency. 